\title{
Various types of autoimmunological diseases of thyroid gland
}

\author{
Stanisław Sporny \\ From 4th Congress of the Polish Thyroid Association 2013 \\ Lodz, Poland. 11-13 April 2013
}

Thyroid gland disease of autoimmune origin presents wide spectrum of pathologies, Graves' disease from one side and chronic thyroiditis with fibrosis and atrophy of gland parenchyma from the other one. Among them the highest number of misunderstandings is observed in pathological reports of chronic thyroiditis in pre-operative cytological as well as in post operative histological examinations. There are numerous classifications of chronic thyroiditis, however they are not widely accepted. Histoclinical classification which correlates elements of microscopic examination with clinical course of the disease seems to be ideal but still does not exist. FNAB of thyroid gland is a method of the greatest importance in the diagnosis of chronic thyroiditis however that fact is not widely understood in every day routine of clinicians and pathologists.

Published: 5 April 2013

Submit your next manuscript to BioMed Central and take full advantage of:

- Convenient online submission

- Thorough peer review

- No space constraints or color figure charges

- Immediate publication on acceptance

- Inclusion in PubMed, CAS, Scopus and Google Scholar

- Research which is freely available for redistribution

\section{Biomed Central}

